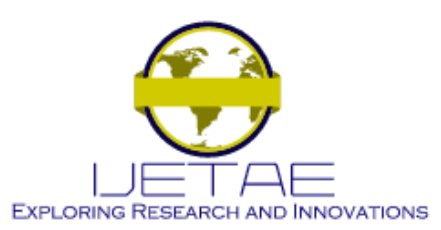

International Journal of Emerging Technology and Advanced Engineering

Website: www.ijetae.com (ISSN 2250-2459, ISO 9001:2008 Certified Journal, Volume 10, Issue 09, September 2020)

\title{
Analysis of Factors that Influence Productivity through Algorithmic Models
}

\author{
Dr. Samuel Lara Escamilla ${ }^{1}$, MSHO. Guillermina Torres Arreola ${ }^{2}$ \\ ${ }^{I}$ Professor of the Division of Postgraduate Studies and Research at National Technology of Mexico, Technological Institute of \\ Tlalnepantla. \\ ${ }^{2}$ Professor of the Industrial Engineering Department at National Technology of Mexico, Technological Institute of Tlalnepantla.
}

\begin{abstract}
- this research article emerges to present an analysis of algorithmic models based on operations research and determine the factors that influence productivity.
\end{abstract}

Keywords - Linear programming, Operations Research, Hungarian Method, productivity, ergonomics

\section{INTRODUCTION}

In many practical problems associated with the solution of a linear programming model as support for decision making, the set of fully known parameters or data cannot be considered or determined, because in various applications such data varies significantly by means of experimentation and analysis, or simply according to the experience of the decision maker. An example of this is the generalized transportation costs associated with a trip between two zones with a route of longer or shorter displacement, which includes the costs associated with the assessment of the waiting time, of access and travel in each way, with the inclusion of the rate that may vary according to the raw materials to displace, the schedule and weight of these products.

To find a solution to these types of problems and generate more robust results in various areas of engineering and science, several mathematical and statistical methods and techniques have been used. Within the most known are stochastic or probabilistic optimization, where the parameter set is assumed they are random, but there are associated probability distributions

This research is based on the theory of linear programming where it will be assumed that the generalized costs have as a parameter a membership interval associated with the possible variations of these values, which allows generate a sensitivity analysis a priori of the solution of the model, in this way, it is proposed to solve by means of a formulation as a problem of optimization of discrete choices, to obtain valid conclusions on the variations of the parameters..

\section{METHOD DESCRIPTION}

Linear programming is a logical-mathematical method, which is used in operations research to favour the modelling of variables, thus generating the solution of quantitative problems, and that are designed and developed by identifying variables and the construction of an objective function, later the mathematical modelling is carried out in order to offer the solution of the equations and an alternate solution.

\section{Problem Statement}

First, it was used the Hungarian method of operations research, where workers are evaluated with different ergonomic methods, such as those shown in Table 1 and 2

Table 1.

Ergonomic evaluation models.

\begin{tabular}{|c|c|c|}
\hline REPETITIVENESS & POSTURAL LOAD & LOAD HANDLIN \\
\hline OCRA & $R U L A$ & $\mathrm{NIOSH}$ \\
\hline $\begin{array}{l}\text { fast evaluation of the } \\
\text { risk associated with } \\
\text { movements repetitive } \\
\text { members superior. }\end{array}$ & $\begin{array}{l}\text { evaluate the exposure } \\
\text { of workers to } \\
\text { maintenance risks of } \\
\text { inappropriate } \\
\text { postures that they } \\
\text { can cause disorders in } \\
\text { the upper body } \\
\text { members }\end{array}$ & $\begin{array}{l}\text { The NIOSH } \\
\text { equation allows to } \\
\text { identify risks } \\
\text { homework related } \\
\text { in which they are } \\
\text { performed manual } \\
\text { surveys of load } \\
\text { intimately related } \\
\text { to injuries lumbar. }\end{array}$ \\
\hline
\end{tabular}

\begin{tabular}{|c|c|c|}
\hline JSI & REBA & GINSHT \\
\hline $\begin{array}{l}\text { JSI assesses related risks } \\
\text { with the upper } \\
\text { extremities. To from } \\
\text { semi-quantitative data } \\
\text { offers a numerical result } \\
\text { that grows with the risk } \\
\text { associated with the } \\
\text { task. }\end{array}$ & $\begin{array}{l}\text { The Reba method } \\
\text { evaluates the } \\
\text { exposure of workers } \\
\text { to risk factors that } \\
\text { may cause traumatic } \\
\text { disorders cumulative } \\
\text { due to load dynamic } \\
\text { and static postural. }\end{array}$ & $\begin{array}{l}\text { GINSHT assesses } \\
\text { risks related to } \\
\text { handling load } \\
\text { manual developed } \\
\text { by the Institute } \\
\text { National Security e } \\
\text { Work Hygiene }\end{array}$ \\
\hline
\end{tabular}




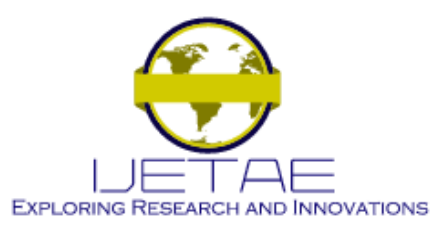

International Journal of Emerging Technology and Advanced Engineering Website: www.ijetae.com (ISSN 2250-2459, ISO 9001:2008 Certified Journal, Volume 10, Issue 09, September 2020)

Table 2.

Ergonomic evaluation models

\begin{tabular}{|c|c|}
\hline BIOMECHANICS & THERMAL ENVIRONMENT \\
\hline BIOMECHANICAL ANALYSIS & FANGER \\
\hline $\begin{array}{l}\text { BIO - MEC conducts evaluations } \\
\text { stress biomechanics static coplanar } \\
\text { from the adopted posture, load } \\
\text { and frequency and duration of } \\
\text { efforts Lets know the risk of } \\
\text { overload by joint, maximum load } \\
\text { recommended, and the stability of } \\
\text { the posture. }\end{array}$ & $\begin{array}{l}\text { The Fanger method allows } \\
\text { estimate thermal sensation global } \\
\text { of those present in a thermal } \\
\text { environment determined by the } \\
\text { middle Vote calculation dear } \\
\text { (PMV) and the percentage of } \\
\text { people unsatisfied (PPD). }\end{array}$ \\
\hline
\end{tabular}

For the Hungarian method it can already be seen with the ergonomic evaluation of some of these factors in the table number 3 .

Table 3. Evaluation in percentage of 4 ergonomic factors that can affect productivity (stress, repetitiveness, effort and bad postures), all of them taken $100 \%$ for better data management.

Table 3.

Comfort level

\section{EMPLOYEE 1/ PRODUCTION FACTOR PRODUCTION/FACTOR MACHINE 1}

$\begin{array}{cccc}\text { Stress } & 70 \% & 90 \% & 70 / 90=0.77 \\ \text { Repetitiveness } & 50 \% & 80 \% & 50 / 80=0.62 \\ \text { Effort } & 90 \% & 30 \% & 90 / 30=2 \\ \text { Bad postures } & 80 \% & 40 \% & 80 / 40=2 \\ & & & \text { Comfort level }=6.39\end{array}$

Once the comfort level of each worker with respect to a machine has been obtained, we will proceed to determine comfort levels with all the proposed combinations. After that, comfort levels will be reflected in the Hungarian method network.
This algorithm is used to Solve minimization problems, it is more effective than the employee to solve the transport problem by the high degree of degeneration that allocation problems may present, under this perspective it was decided use it, as shown in figure 1.

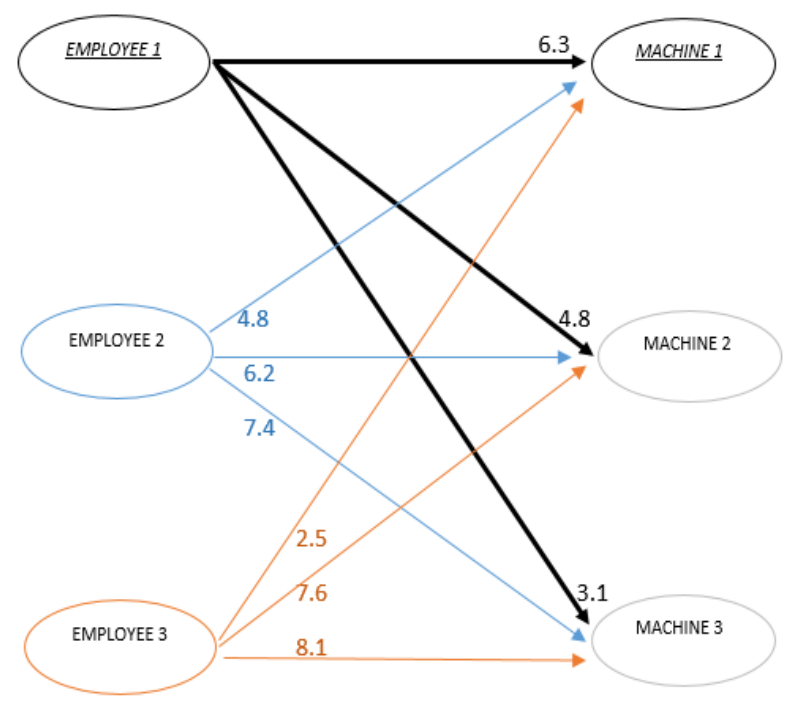

Figure 1. Model based on the hungarian method

The Hungarian method is a method of optimization of allocation problems, of minimization only, since which is more effective in solving the transport problem due to the high degree of degeneration that may occur assignment problems

Assignment problems include applications such as assigning people to tasks. Although their Applications seem to differ from those of the transport problem, it constitutes a particular case. The problems of transport and allocation are particular cases of a larger group of problems, called flow problems in networks.

The network is developed, and it is solved by the Hungarian method.

First: find the smallest of the data in each row

Second: subtract the data from each of the data from the entire row

Third: subtract the data in each of the data from the entire column

Fourth: identify the values considered with zero, for the optimal solution

With the solution to the problem, using the Hungarian method, the highest level is observed, in the man-machine relationship, as shown in table 4. 


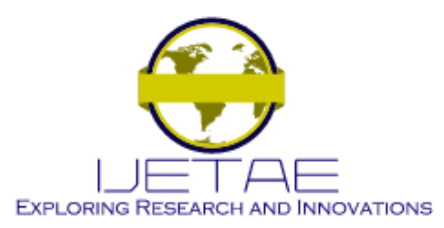

International Journal of Emerging Technology and Advanced Engineering Website: www.ijetae.com (ISSN 2250-2459, ISO 9001:2008 Certified Journal, Volume 10, Issue 09, September 2020)

Table 4.

Assignment of operators to machines, to obtain the maximum level of comfort.

\begin{tabular}{|c|c|c|c|}
\hline $\begin{array}{c}\text { EMPLOYEE } \\
\text { AAACHINE }\end{array}$ & MACHINE 1 & MACHINE 2 & MACHINE 3 \\
\hline EMPLOYEE 1 & 6.3 & 4.8 & 3.1 \\
\hline EMPLOYEE 2 & 4.8 & 6.2 & 7.4 \\
\hline EMPLOYEE 3 & 2.5 & 7.6 & 5.1 \\
\hline EMPLOYEE 1 & 0 & 2.8 & 5 \\
\hline EMPLOYEE 2 & 1.5 & 1.4 & 0.7 \\
\hline EMPLOYEE 3 & 4.8 & 0 & 0 \\
\hline EMPLOYEE 1 & 0 & 2.8 & 5 \\
\hline EMPLOYEE 2 & 0.8 & 0.7 & 0 \\
\hline EMPLOYEE 3 & 4.8 & 0 & 0 \\
\hline \multicolumn{2}{|c|}{ EMPLOYEE 1 ----- MACHINE 1 } & 6.3 \\
\hline \multicolumn{2}{|c|}{ EMPLOYEE 2 ------ MACHINE 3 } & 7.6 \\
\hline \multicolumn{2}{|c|}{ EMPLOYEE 3 ----- MACHINE 2 } & 7.4 \\
\hline \multicolumn{2}{|c|}{ MAXIMUM LEVEL OF COMFOR } & 21.3 \\
\hline
\end{tabular}

\section{CONTRIButions Of Our Project.}

This paper proposes a linear programming formulation under the principles of the Hungarian method, it is possible mention that there is no ergonomic evaluation that supports a calculation of comfort in the workers, so the present investigation intends to contribute under the research principles of operations the relevance of formulating algorithms for productivity.

\section{GENERAL CONCLUSIONS}

As a general conclusion, the model presented generates a solution closer to the comfort that a worker in the industry, since many times the productivity defined in parts, numbers, percentages and money, without taking into account the health of the worker, is why it is intended to develop an algorithm that allows offer an approach to work development without affecting the worker at present and prevent in the future injuries and / or ergonomic diseases, such as those presented in this work, including stress, repetitions, effort, bad postures and others.

\section{REFERENCES}

[1] MUNCH GALINDO, LOURDES. Fundamentos de administración. $5^{\mathrm{a}}$ ed. $4^{\mathrm{a}}$ reimp., México, MX: Editorial: Trillas, 2015

[2] Porter, M. (1 de Ene de 2008). Harvard Business Review. H. B. Publishing. [En línea]. Disponible en: http://hbr.org/product/the-fivecompetitive-forces-that-shape-strategy/an/R0801E-PDFENG. [Fecha de acceso: 20 de octubre de 2011].

[3] Duncan, A. J. (2010). Quality Control and Industrial Statistics. 4th Ed., Irwin, Homewoods, III.

[4] LIND, MARCHAL, WATHEN, Estadística Aplicadas a los Negocios y la Economía, Mc Graw Hill, México 2012.

[5] TAHA, HAMDY A. Investigación de operaciones, $7^{\text {a }}$ edición Pearson, Educación, México, 2004.

[6] EPPEN, G.D. Investigación de operaciones en la ciencia Administrativa PRENTICE-HALL, México, 2000.

[7] JAMES, H. GREENE Control de la Producción Sistemas y Decisiones, DIANA, México 1986.

[8] GRANT L. EUGENE, RICHARD S. LEAVENWORTH Control Estadístico de Calidad, CECSA, México 2004.

[9] MARQUEZ PEREZ MARIA, Control de Calidad Tecnicas y Herramientas, Ed. Alfa Omega, México 2014.

[10] BACA URBINA GABRIEL, Evaluación de Proyectos , Ed. MacGraw Hill, México 2013.

[11] WAYNE L. WINSTON, Investigación de Operaciones, Aplicaciones y Algoritmos, Grupo Editorial Iberoamericano 1994.

[12] MARQUEZ ELIAS, MIGUEL A. Probabilidad y Estadística, Ed. Prentice Hall, México 2007.

[13] BRENSON MARK L, LEVINE DAVID M. Estadística Básica en Administración, Ed. Prentice Hall, México 1996.

[14] ANGULO AGUIRRE LUIS, Proyectos Formulación y Evaluación, Ed. Alfa Omega, Mexico 2016

[15] RENDER et al. Metodos Cuantitativos para los Negocios, Ed. Pearson, México 2016.

[16] Martínez, f. Access, the economic link in transport-land use interaction. Transportation Research b. 1995, vol. 29, núm. 6, pp. 457-47.

[17] Loomba, n.p. Linear programming: an introductory analysis. Mcgraw-hill, new york, 1964 Universidad peruana unión - biblioteca central - libro número 0.001245/f12 programación lineal

[18] Díaz parra, o. Y cruz chávez, m.a. El problema del transporte. Cuernavaca, morelos: Centro de investigación en ingeniería y ciencias aplicadas, 2006. 